\title{
LEADERSHIP WITHIN RELIGIOUS-BASED SCHOOL IN MALAYSIA: A META-ANALYSIS STUDY
}

\author{
Zunaidi Harun \\ Universiti Malaya, Kuala Lumpur \\ zunaidi.harun@gmail.com \\ Muhammad Faizal A. Ghani \\ Universiti Malaya, Kuala Lumpur \\ mdfaizal@um.edu.my \\ Norfariza Mohd Radzi \\ Universiti Malaya, Kuala Lumpur \\ norfariza@um.edu.my \\ Zawawi Ismail \\ Universiti Malaya, Kuala Lumpur \\ zawawiismail@um.edu.my
}

DOI: 10.35719/jieman.v3i1.67

\begin{abstract}
Abstrak
Kajian ini bertujuan untuk meneliti beberapa artikel hasil penelitian tentang kepala sekolah agama di Malaysia. Secara khusus, penelitian ini bertujuan untuk mengidentifikasi gaya kepemimpinan para kepala sekolah agama. Kajian ini menggunakan metode meta-analisis yang menganalisis secara statistik beberapa artikel hasil penelitian yang diterbitkan dalam beberapa tahun terakhir. Sebanyak dua belas artikel tentang kepala sekolah agama di Malaysia yaitu dari tahun 2007 hingga 2020 telah dianalisis secara sistematik menggunakan metode MetaAnalysis. Hasil kajian mengungkap bahwa gaya kepemimpinan yang banyak digunakan adalah kepemimpinan instruksional, transformasional, Rabbani dan kepemimpinan berkelanjutan. Hasil utama kajian
\end{abstract}


sebagaimana yang ditetapkan dalam tujuan penelitian ini adalah mengidentifikasi efektivitas kepemimpinan yang diterapkan di kalangan kepala-kepala sekolah agama di Malaysia dan pengaruh beberapa variabel penelitian seperti gaya kepemimpinan dan lingkungan sekolah. Implikasi kajian ini adalah agar pihak-pihak yang berkepentingan dalam bidang pendidikan perlu menyadari pentingnya data hasil penelitian sebagai dasar pembuatan kebijakan.

Kata Kunci: kepala sekolah agama, meta-analysis, Malaysia

\begin{abstract}
This study aims to examine some research articles about religious-based school leaders in Malaysia. Specifically, the study is to identify common styles of leadership applied among religious-based school leaders. This study used a meta-analysis method which statistically analyzed some research articles over certain years. A total of twelve research articles about religious-based school leaders in Malaysia from the years of 2007 through 2020 were analyzed systematically using Meta-Analysis. The research findings on the most commonly use leadership style are instructional, transformational, Rabbani and sustainable leaderships. The most research findings to respond to the research objectives are to identify the effectiveness of the leadership applied among religious-based school leaders in Malaysia and influences of some research variables such as the leadership style and school environment. The research implication is to be aware among educational stakeholders about the importance of research data in making school decision.
\end{abstract}

Keywords: religious-based school leaders, meta-analysis, Malaysia

\title{
Introduction
}

Leadership is a complex process because it involves three main components; leaders, followers, and context, or also known as environmental factors. These three components are complementary and cannot be separated from each other. ${ }^{1}$ The main principle underlies a good leadership is the one complying with the context

${ }^{1}$ Ahamad Faosiy Ogunbado, et al. "Islamic Perspective of the Followers: A Neglected Aspect in Locus of Leadership." International Review of Management and Marketing, Volue 6 Issue 8 (Special Issue) (2016), 113-118. 
JIEMAN: Journal of Islamic Educational Management

and environment. ${ }^{2}$ The same thing happens for the religious-based schools.

Furthermore, based on the research highlights, it was found that there were some studies related to leadership within religiousbased schools, although the numbers were very small. Hailan and Rahimah's ${ }^{3}$ study focuses on the rabbinic leadership level of principals in religious-based national schools, more specifically, it is a survey study based on the perceptions of teachers and principals, identifying an effective school management practices among administrators of integrated religious-based primary schools in State of Selangor. ${ }^{4}$ Like Jamalullail, he also studied leadership practices, but focusing more on the principal of the Sekolah Agama Berbantuan Pemerintah (Government Assisted Religion-based School), also known as SABK, in Pontian Regency. ${ }^{5}$ Whereas, studies to determine the relationship between the principal's leadership style and some other variables, was carried out by Nurlaili and Mohd Yusof, ${ }^{6}$ and Jamalulail. ${ }^{7}$

However, after a long time, there has been no specific effort to collect and analyze the research done in the field of leadership

${ }^{2}$ Simon Clarke and Tom O’Donoghue, "Educational Leadership and Context: A Rendering of an Inseparable Relationship." British Journal of Educational Studies, (2016), 167-182.

${ }^{3}$ Hailan Salamun, B., \& Rahimah Hj. Ahmad, "Daya kepimpinan rabbani pengetua Sekolah Menengah Kebangsaan Agama (SMKA). In Institut Aminudin Baki (Ed.)", Seminar Nasional Pengurusan dan Kepimpinan Pendidikan ke-17 (2010) (p. 56).

${ }^{4}$ Abdul Wahab Jamalullail, et. al., "Amalan Pengurusan Sekolah Berkesan Pentadbir Sekolah Rendah Agama Intergrasi Negeri Selangor.” Jurnal Pengurusan dan Kepimpinan Pendidikan, Vol. 24 Issue 2 (2012), 31-43.

${ }^{5}$ Fauzi Sulehan, "Amalan kepimpinan lestari pengetua Sekolah Agama Bantuan Kerajaan (SABK) di Daerah Pontian,” Universiti Teknologi Malaysia, 2013

6 Nurlaili Abd Wahab and Mohd Yusof Abdullah, "Hubungan Gaya Kepimpinan dan Pengurusan Kerja Guru Besar dengan Kepuasan Kerja Guru Sekolah Agama Kerajaan Johor," Jurnal Ilmi, 8 (2018), 136-150.

7 Abdul Wahab Jamalullail, et. al., "Hubungan Antara Gaya Kepimpinan Pengetua dengan Motivasi Guru Sekolah Menengah Agama,” Jurnal Pengurusan dan Kepimpinan Pendidikan, Vol. 17 Issue 2 (2007). 
within religious-based school in Malaysia, while many of the metaanalytical studies conducted in other areas of leadership such as the study by Bolden that explore the development of the distributive concept of leadership and how its use varies relatively between countries, public, and private sector. ${ }^{8}$

Therefore, this meta-analysis study related to leadership within religious-based school offers a strong justification for reviewing and subsequently producing a set of leadership research domains that include leadership approaches or styles, types of research methods used, and summaries of previous research findings. This justification is in line with the notions of the metaanalytic studies' influences for being able to generate a series of conclusions from the findings of past studies. ${ }^{9}$

Thus, by consolidating studies related to leadership within religious-based school, it is expected that it can lead for further studies to be done to fill the gaps in terms of research domains and methods which can improve the quality and validity of the research findings themselves. Considering this matter, this study aims to; (a) examine the domain of leadership research in religious-based schools, (b) identify the research methods used in leadership within religious-based school research, and (c) analyze the foremost findings of the study related to religious studies and school's leadership.

\section{Literature Review}

\section{History of Religious-based Education in Malaysia}

Islamic education in Malaysia has started since Islam took significant role in Melaka around the $14^{\text {th }}$ century. At that time, Islamic education was taught in an informal form in mosque,

${ }^{8}$ Richard Bolden, "Distributed Leadership in Organisations: A Review of Theory and Research," International Journal of Management Reviews, 13, (2011), 251-269.

${ }^{9}$ Esteban Walker, Adrian V. Hernandez, and Michael W. Kattan, "MetaAnalysis: Its Strengths and Limitations," Cleveland Clinic Journal of Medicine, Vol. 75 Issue 6 (2008), 431-439. 
JIEMAN: Journal of Islamic Educational Management

Islamic Boarding Schools and madrasas. ${ }^{10}$ It taught about a commitment to do da'wah or preaching and establishing public awareness. In this time, there was no regulation for the teaching and learning process of Islamic education. After the arrival of European colonizers, Islamic education began to be hampered with the devious British method of disrupting religious-based schools turned into Malay schools. ${ }^{11}$ Moreover, the establishment of an English language school dedicated to the Malay elite at that time aiming to train the young leaders who looked up for the West practitioners to give contribution to religious-based education, which had drawn attention among Malays, to eliminate the religious-based education in schools, when Jawi was the only one taught as part of the syllabus. The colonialists placed religiousbased education under the Malay Rulers and the British which did not provide any assistance which led to the advancement of religious-based schools. ${ }^{12}$

However, after Malaya's independence in 1957, Islamic education began to be included within the implementation of an educational law based on the Razak and Rahman Thalib Statements 1956 1960. After the 1961 Education Law was enacted, the teaching of Islam was officially introduced to ultimately bring major changes to the Islamic education which ultimately led to the establishment of a Sekolah Menengah Keagamaan (Religious-based High School), or SMKA, through the rebranding of existing schools. ${ }^{13}$

${ }^{10}$ Asmawati Suhid, B., Abd Muhsin Ahmad, B., Syaza Mohd Sabri, B., \& Azreen Effendy Mohamad, B. Pendidikan untuk semua: Amalannya dalam sistem Pendidikan Islam di Malaysia," International Journal of Education and Training (InjET), Vol. 1 Issue 5 (2015), 1-7; Mohd Roslan Mohd Nor, B., \& Wan Mohd Tarmizi Wan Othman, B. "Sejarah dan Perkembangan Pendidikan Islam di Malaysia,” Jurnal Al-Ta'dib, Vol. 6 Issue 1 (2011), 1-20.

${ }^{11}$ Mohd Hairudin Amin and Kamarul Azmi Jasmi. Sekolah agama di Malaysia: Sejarah, Isu dan Cabaran. Univerti Teknologi Malaysia, 2012.

12 Ibid.

${ }^{13}$ Mohd Roslan Mohd Nor, B., \& Wan Mohd Tarmizi Wan Othman, B. Sejarah dan perkembangan Pendidikan Islam di Malaysia. Jurnal Al-Ta'dib, Vol. 6 Issue 1 (2011), 1-20. 


\section{Methods}

\section{Research Method}

The objective of this study is to collect, evaluate, and summarize studies of Madrasa's leadership that have been carried out in Malaysia. Based on these objectives, the researcher has chosen a modified meta-analysis method from the Preferred Reporting Items for Systematic Review and Meta-Analyzes Protocol. ${ }^{14}$ The meta-analysis method is a method that statistically and systematically analyzes the findings of previous studies to produce a set of conclusions of findings as described by Dundum. ${ }^{15}$ The same topic has previously been discussed by Webster and Watson, ${ }^{16}$ and Walker. ${ }^{17}$ However, Walker's explanation is more indepth as he explains that combining several studies into one study can increase the research reliability level. Research consolidation involves not only findings, but also sample size, methods and others. Likewise, this study focuses more on the production of summary sets as described by Walker. A study by Moher et al. ${ }^{18}$ is one of the studies that uses PRISMA as a guide in the implementation of meta-analysis research.

${ }^{14}$ PRISMA. (2020). PRISMA 2020. In PRISMA (Vol. 49, Issue 1, pp. 4044).

${ }^{15}$ Uldarico Rex Dumdum, Kevin B. Lowe, and Bruce J. Avolio. "A metaAnalysis of Transformational and Transactional Leadership Correlates of Effectiveness and Satisfaction: An Update and Extension," In Transformational and Charismatic Leadership: The Road Ahead 1oth Anniversary Edition. Emerald Insight, Vol. 2 (2015) pp. 35-66.

${ }^{16}$ Jane Webster and Richard T. Watson, "Analyzing the Past to Prepare for the Future: Writing a Literature Review," MIS Quarterly, Vol. 26 Issue 2 (2002), xiii-Xxiii.

${ }^{17}$ Walker, Hernandez, \& Kattan, "Meta-Analysis," 431-439.

${ }^{18}$ David Moher, et al. "Preferred Reporting Items for Systematic Review and Meta-Analysis Protocols (Prisma-P) 2015 Statement." Systematic Reviews Journal, Vol. 4 Issue 1 (2015), 3-9. 


\section{Criterias within Chosen Sampling Method}

The main thing to consider in this meta-analysis study is the journal article selection criteria. Based on Moher's ${ }^{19}$ and, Webster's and Watson's, ${ }^{20}$ researchers have determined several main criteria for selecting articles to be analyzed in this study, such as (i) the scope of study in the field of leadership that focuses on religious values. school leadership; (ii) the research sample is only among religious-based school principals in Malaysia; (iii) open to all types of study designs used; (iv) open to all types of research approaches used, whether qualitative, quantitative and others; (v) limited to two languages; Malay and English (vi) limited to articles/study of leadership published in 2007 to 2020 only. According to Walker, ${ }^{21}$ these criteria are an important component of meta-analytic studies. This is because, through the established criteria, it can certify and ensure that the research carried out is in accordance with the targeted objectives.

\section{Research Resources and Seeking Strategies}

In terms of resources, several databases subscribed to by the University of Malaya libraries such as Scopus, CLJ Law, Emerald, Science Direct, Proquest, and SAGE Journal, Aminuddin Baki Institute (IAB) repository, Malaysian Ministry of Education Library are used to find information related to articles. Moreover, the search engines of Google Scholar and Google Search are also used to ensure a wider range of searches performed. The article uses keywords such as "Leadership within Religious-based School", "Religious School Leadership", "SABK", "SMKA", "Religious-based School", "School Leadership".

${ }^{19}$ David Moher, et al. Preferred reporting items for systematic review and meta-analysis protocols (prisma-p) 2015 statement. Systematic Reviews Journal, Vol. 4 Issue 1 (2015), 3-9.

${ }^{20}$ Webster \& Watson, "Analyzing," xiii-xxiii.

${ }^{21}$ Walker, Hernandez, \& Kattan, "Meta-Analysis," 431-439. 


\section{Research's Sample Selection Process}

After setting the criteria for selecting articles, the studies that meets the criteria is re-screened to select studies that truly meets the required quality characteristics according to the research objectives. Consistent with Walker's suggestion that the selection of studies should be carried out through the two stages; first, to identify potential and relevant studies to the objectives of this study; second, selecting studies in detail using the selection criteria that have been set as mentioned above. Articles that do not meet the criteria will be rejected. ${ }^{22}$

Finally, a total of 12 articles were identified to meet the criteria set out in Table 1 below:

Table 1. List of Articles Related to Leadership within Religious-based School in Malaysia

\begin{tabular}{|c|c|c|c|}
\hline No. & Researcher (Year) & $\begin{array}{l}\text { Types/ Sample } \\
\text { Size }\end{array}$ & $\begin{array}{l}\text { Research } \\
\text { Approach }\end{array}$ \\
\hline 1. & Chitra A/P Sinnu (2019) & Teacher: 155 & Quantitative \\
\hline 2. & $\begin{array}{l}\text { Samsiah binti Si-Rajab dan Khalip } \\
\text { Musa (2019) }\end{array}$ & Teacher: 365 & Quantitative \\
\hline 3. & $\begin{array}{l}\text { Nurlaili Abd Wahab dan Mohd Yusof } \\
\text { Abdullah (2018) }\end{array}$ & Teacher: 300 & Quantitative \\
\hline 4. & $\begin{array}{l}\text { Dg. Maimunah Hj. Sidek dan Dg. } \\
\text { Norizah Ag. Kiflee (2017) }\end{array}$ & Teacher: 103 & Quantitative \\
\hline 5. & $\begin{array}{l}\text { Mohd Nor Jaafar dan Jazmi Isa } \\
(2015)\end{array}$ & Teacher: 607 & Quantitative \\
\hline 6. & $\begin{array}{l}\text { Jamelaa Bibi Abdullah dan Jainabee } \\
\text { Md Kassim (2013) }\end{array}$ & $\begin{array}{l}\text { Principal: } 6 \\
\text { Teacher: } 6\end{array}$ & Qualitative \\
\hline 7. & $\begin{array}{l}\text { Hailan Salamun \& Rahimah Hj. } \\
\text { Ahmad (2012) }\end{array}$ & $\begin{array}{l}\text { Principal: } 45 \\
\text { Teacher: } 763 \\
\text { Temu bual: } \\
\text { Principal: } 12\end{array}$ & $\begin{array}{l}\text { Mixed } \\
\text { Methods }\end{array}$ \\
\hline 8. & $\begin{array}{l}\text { Jamalullail Abdul Wahab, Nor'azlin } \\
\text { Salamun@Mohamed, Ameer Hazim } \\
\text { Mustapa, Fairous Ismail, Md. Fuad } \\
\text { Md. Rafik (2012) }\end{array}$ & Teacher: 75 & Quantitative \\
\hline
\end{tabular}


JIEMAN: Journal of Islamic Educational Management

\begin{tabular}{clll}
\hline No. & Researcher (Year) & $\begin{array}{l}\text { Types/ Sample } \\
\text { Size }\end{array}$ & $\begin{array}{l}\text { Research } \\
\text { Approach }\end{array}$ \\
\hline 9. & $\begin{array}{l}\text { Lokman Mohd. Tahir dan Robiah } \\
\text { Sidin (2008) }\end{array}$ & $\begin{array}{l}\text { Principal: } 34 \\
\text { Teacher: } 1705\end{array}$ & Quantitative \\
10. & $\begin{array}{l}\text { Jamalullail Abdul Wahab, dan Zawiah } \\
\text { Teacher: } 96\end{array}$ & Quantitative \\
Kamad (2007) & $\begin{array}{l}\text { Azizi Abu Bakar, Mohd Nor Jaafar, } \\
\text { Jazmi Md. Isa dan Shuhairimi }\end{array}$ & $\begin{array}{l}\text { *Principals } \\
\text { (for the entire } \\
\text { Abdullah (2014) }\end{array}$ & Quantitative \\
12. & $\begin{array}{l}\text { Shabita Md. Hussain dan \& Azlin } \\
\text { Norhaini Mansor (2016) }\end{array}$ & Teacher: 84 \\
& Note: * All SAR principals in the State of Kedah & Quantitative \\
\hline
\end{tabular}

\section{Research Finding}

The findings of this study are arranged based on three main parts from the research objectives:

The Objective of Study 1: To examine the domain of leadership within religious-based school studies carried out in Malaysia.

The Main Domain of Study. The analysis results of the leadership approach which is the domain of Madrasa's leadership studies, it was found there are six main domains that underlie the research; (a) instructional leadership, (b) transformational leadership, (c) leadership style, (d) rabbinic leadership, (e) effective managerial practices, and (e) sustainable leadership. The details are as follows in Table 2:

Table 2. List of Main Areas of Leadership within Religious-based School Studies in Malaysia

\begin{tabular}{clc}
\hline No. & The Research's Main Domain & Number of Research \\
\hline 1. & Instructional Leadership & 3 \\
2. & Transformational Leadership & 2 \\
3. & Leadership Style & 4
\end{tabular}




\begin{tabular}{clc}
\hline No. & The Research's Main Domain & Number of Research \\
\hline 4. & Rabbinic Leadership & 1 \\
5. & Effective Managerial Practices & 2 \\
6. & Sustainable Leadership & 1 \\
\hline
\end{tabular}

Based on Table 2, the most focused domain in the research sample related to madrasah's leadership is leadership style, followed by instructional leadership and transformational leadership respectively. In addition, the rabbinic leadership style, effective management practices, and sustainable leadership were also studied by previous researchers.

Study subdomain. Through the analysis of similarities and differences in the focus/subdomain of the study, sixteen subdomains of the study of madrasa leadership were found. More details as in Table 3 below:

Table 3. List of Subdomains of Leadership within Religious-based School Studies in Malaysia

\begin{tabular}{llll}
\hline No. & Main Domain & Subdomain & $\begin{array}{c}\text { Frequency } \\
(f)\end{array}$ \\
\hline 1. & $\begin{array}{l}\text { Instructional } \\
\text { Leadership }\end{array}$ & $\begin{array}{l}\text { Its relationship with teacher's work } \\
\text { commitment }\end{array}$ & 1 \\
& & $\begin{array}{l}\text { Identifying the stage of practice } \\
\text { Practice checking }\end{array}$ & 1 \\
& & Its effect on teacher's efficacy & 1 \\
\hline 2. & Transformational & 1 \\
& Leadership & Identifying the stage of practice & 1 \\
& & Its effect on work commitment & 1 \\
\hline 3. & Leadership Style & $\begin{array}{l}\text { Its relationship with job satisfaction } \\
\text { Its influence on work motivation }\end{array}$ & 1 \\
& & $\begin{array}{l}\text { Identification of leadership style based } \\
\text { on the model of Bolman and Deal (1991) }\end{array}$ & 1 \\
& & A review of leadership style & 1 \\
\hline 4. & Rabbinic & $\begin{array}{l}\text { Identifying the stage of rabbinic } \\
\text { leadership }\end{array}$ & 1 \\
\hline
\end{tabular}


JIEMAN: Journal of Islamic Educational Management

\begin{tabular}{lllc}
\hline No. & Main Domain & Subdomain & $\begin{array}{c}\text { Frequency } \\
(f)\end{array}$ \\
\hline 5. & $\begin{array}{l}\text { Effective } \\
\text { Managerial } \\
\text { Practices }\end{array}$ & Identifying the stage of practice & 1 \\
\hline 6. & $\begin{array}{l}\text { Sustainable } \\
\text { Leadership }\end{array}$ & $\begin{array}{l}\text { Identifying the stage of sustainable } \\
\text { leadership }\end{array}$ & 1 \\
\hline
\end{tabular}

From the analysis conducted, the most comprehensive leadership style domains are 4 subdomains that focus on studying the relationship of leadership style with teacher's job satisfaction, studying the influence of leadership style on teacher work motivation, identifying leadership styles and conducting a survey on leadership styles found in religious-based schools. Next, it is followed by a subdomain under instructional leadership which focuses on examining the relationship of instructional leadership with teacher's work commitment, and the level of instructional leadership. Researchers, in the field of instructional leadership, also conducted a qualitative examination to explore the practice of instructional leadership among religious-based school leaders.

In addition, transformational leadership also seems to be the main concern of previous researchers. There are three sub-domains studied, such as the effect of transformational leadership style on teacher's effectiveness, identifying the level of transformational leadership practice among leaders and its effect on teacher's work commitment. The domain of effective managerial practice has two subdomains, such as studying the relationship between effective management and job satisfaction and the level of effectiveness of management practices among madrasah's leaders. Under sustainable leadership, there are two subdomains that identify the level and influence of teacher's work commitment. Lastly, rabbinic leadership, which focuses on a study of the level of rabbinic leadership practice among religious-based school leaders. 
The Objective of Study 2: To identify research methods that have been used in studies of leadership within religious-based school in Malaysia

Study approach and design. Table 4 shows the approaches and research designs that have been used by previous researchers regarding leadership in Malaysia.

Table 4. Approach and Design of Leadership within Religious-based School Studies in Malaysia

\begin{tabular}{|c|c|c|c|c|}
\hline No. & Approach & $\begin{array}{l}\text { Design \& } \\
\text { Frequency } \\
(f)\end{array}$ & Analysis & Author (Year) \\
\hline \multirow[t]{2}{*}{1.} & Quantitative & Review (2) & $\begin{array}{l}\text { Percentage, } \\
\text { Frequency, } \\
\text { min, median, } \\
\text { Standard } \\
\text { deviation }\end{array}$ & $\begin{array}{l}\text { Samsiah binti Si-Rajab, } \\
\text { Khalip Musa }\end{array}$ \\
\hline & & & $\begin{array}{l}\text { Min, } \\
\text { Standard } \\
\text { deviation }\end{array}$ & $\begin{array}{l}\text { Jamalullail Abdul Wahab, } \\
\text { Nor'azlin } \\
\text { Salamun@Mohamed, Ameer } \\
\text { Hazim Mustapa, Fairous } \\
\text { Ismail, Md. Fuad Md. Rafik } \\
\text { (2012) }\end{array}$ \\
\hline \multirow[t]{5}{*}{2.} & & $\begin{array}{l}\text { Correlation } \\
\text { (8) }\end{array}$ & $\begin{array}{l}\text { Min, Standard } \\
\text { deviation } \\
\text { Correlation } \\
\text { ANOVA, } \\
\text { correlation, } \\
\text { t-test }\end{array}$ & $\begin{array}{l}\text { Nurlaili Abd Wahab dan } \\
\text { Mohd Yusof Abdullah (2018) } \\
\text { Chitra A/P Sinnu (2019) }\end{array}$ \\
\hline & & & t-test, ANOVA & $\begin{array}{l}\text { Dg. Maimunah Hj. Sidek } \\
\text { dan Dg. Norizah Ag. Kiflee } \\
(2017)\end{array}$ \\
\hline & & & $\begin{array}{l}\text { ANOVA, } \\
\text { Regression }\end{array}$ & $\begin{array}{l}\text { Mohd Nor Jaafar dan Jazmi } \\
\text { Isa (2015) }\end{array}$ \\
\hline & & & Regression & $\begin{array}{l}\text { Lokman Mohd. Tahir dan } \\
\text { Robiah Sidin (2008) }\end{array}$ \\
\hline & & & Correlation & $\begin{array}{l}\text { Jamalullail Abdul Wahab, } \\
\text { Zawiah Kamad (2007) }\end{array}$ \\
\hline
\end{tabular}


JIEMAN: Journal of Islamic Educational Management

\begin{tabular}{|c|c|c|c|c|}
\hline No. & Approach & $\begin{array}{c}\text { Design \& } \\
\text { Frequency } \\
(f)\end{array}$ & Analysis & Author (Year) \\
\hline & & & $\begin{array}{l}\text { ANOVA, } \\
\text { Regression } \\
\text { Correlation }\end{array}$ & $\begin{array}{l}\text { Azizi Abu Bakar, Mohd Nor } \\
\text { Jaafar, Jazmi Md. Isa, } \\
\text { Shuhairimi Abdullah (2014) } \\
\text { Shabita Md. Hussain dan \& } \\
\text { Azlin Norhaini Mansor } \\
\text { (2016) }\end{array}$ \\
\hline 3. & Qualitative & Exploration & $\begin{array}{l}\text { Interviews } \\
\text { Observation } \\
\text { Document } \\
\text { Analysis }\end{array}$ & $\begin{array}{l}\text { Jamelaa Bibi Abdullah dan } \\
\text { Jainabee Md Kassim (2013) }\end{array}$ \\
\hline 4. & $\begin{array}{l}\text { Mixed } \\
\text { methods }\end{array}$ & $\begin{array}{l}\text { Mixed } \\
\text { methods }\end{array}$ & $\begin{array}{l}\text { Min, } \\
\text { percentage }\end{array}$ & $\begin{array}{l}\text { Hailan Salamun dan } \\
\text { Rahimah Hj. Ahmad (2012) }\end{array}$ \\
\hline
\end{tabular}

As described in Table 4, it was found that researchers prefer to use a quantitative approach. However, out of the 12 studies selected, one of them used qualitative methods and another one used a mixed approach. Meanwhile, in the context of research design, it was found that most of the research samples used a correlation design that involved correlation analysis, ANOVA, ttest, and regression, followed by survey studies.

Study Sample Profile. After analyzing the profile of the research sample related to madrasa's leadership, three categories of samples were found; principals, principals and teachers. The sample consisted of principals/principals/teachers of SMKA, SABK, SABK SR, SAN, SRA and Sekolah Rendah Agama Integrasi (SRAI) (Integrated Religious Primary School). Table 5 below shows the profile of the research sample:

Table 5. Profile of the Sample Study of Leadership within Religious-based School in Malaysia

\begin{tabular}{llcc}
\hline No. & Sample Profile & Types of School & Frequency $(f)$ \\
\hline 1. & Principal & SMKA & 3
\end{tabular}




\begin{tabular}{lllc}
\hline No. & Sample Profile & Types of School & Frequency $(f)$ \\
\hline & & SABK & 1 \\
& & SAR & 1 \\
2. & Headmaster & SABK SR & 1 \\
3. & Teacher & SMKA & 5 \\
& & SABK & 2 \\
& SAN & 2 \\
& SAR & 1 \\
& SRAI & 1 \\
& &
\end{tabular}

Note: There are studies that use more than one type of sample

Based on Table 5, SMKA is the most studied type of school. The number is coming from the practice of learning organizations applied in KLH. Next are SABK, SM, and SABK SR.

Data Collection Method. From the results of the analysis carried out, it was found that there were four methods that had bee, $\mathrm{n}$ used by previous researchers, they are; questionnaires, interviews, observation and document analysis. Table 6 shows the data collection methods that have been used.

Table 6. Data Collection Methods Used in the Research Sample

\begin{tabular}{lll}
\hline $\begin{array}{l}\text { Data Collection } \\
\text { Nothod }\end{array}$ & Frequency & \multicolumn{1}{c}{ Author (Year) } \\
\hline Questionnaire & 11 & Samsiah binti Si-Rajab dan Khalip Musa \\
& Nurlaili Abd Wahab dan Mohd Yusof Abdullah \\
& $(2018)$ \\
& Jamalullail Abdul Wahab, Nor'azlin \\
& Salamun@Mohamed, Ameer Hazim Mustapa, \\
& Fairous Ismail, Md. Fuad Md. Rafik (2012) \\
& Chitra A/P Sinnu (2019) \\
& Dg. Maimunah Hj. Sidek dan Dg. Norizah Ag. \\
& Kiflee (2017) \\
& Mohd Nor Jaafar dan Jazmi Isa (2015) \\
& Lokman Mohd. Tahir dan Robiah Sidin (2008)
\end{tabular}


JIEMAN: Journal of Islamic Educational Management

\begin{tabular}{|c|c|c|c|}
\hline No. & $\begin{array}{l}\text { Data Collection } \\
\text { Method }\end{array}$ & Frequency & Author (Year) \\
\hline & & & $\begin{array}{l}\text { Jamalullail Abdul Wahab, Zawiah Kamad (2007) } \\
\text { *Hailan Salamun dan Rahimah Hj. Ahmad } \\
(\text { (2012) } \\
\text { Azizi Abu Bakar, Mohd Nor Jaafar, Jazmi Md. } \\
\text { Isa, Shuhairimi Abdullah (2014) } \\
\text { Shabita Md. Hussain dan \& Azlin Norhaini } \\
\text { Mansor (2016) }\end{array}$ \\
\hline & Interview, & 2 & $\begin{array}{l}\text { *Jamelaa Bibi Abdullah dan Jainabee Md Kassim } \\
\text { (2013) } \\
\text { Hailan Salamun dan Rahimah Hj. Ahmad (2012) }\end{array}$ \\
\hline & Observation & 1 & $\begin{array}{l}\text { *Jamelaa Bibi Abdullah dan Jainabee Md Kassim } \\
(2013)\end{array}$ \\
\hline & $\begin{array}{l}\text { Document } \\
\text { Analysis }\end{array}$ & 1 & $\begin{array}{l}\text { *Jamelaa Bibi Abdullah dan Jainabee Md Kassim } \\
\text { (2013) }\end{array}$ \\
\hline
\end{tabular}

Note: *Uses more than one data collection method.

It was found that most of previous studies done have used more than one data collection method. Questionnaire or survey method is a method that is often used in research samples as an instrument to obtain data from research participants. Next is the interview method, which is used in two studies; qualitative research and research that uses a mixed approach. Only one study used document analysis.

The Objective of Study 3: To analyze the main findings of the study of leadership within religious-based school in Malaysia. In line with the third research objective, the researcher has analyzed the research sample and found that the main findings of the previous research can be divided according to the following themes:

\section{Theme One: Levels of Leadership Practice}

From the analysis of the research sample, it was found that previous researchers who studied the field of leadership within religious-based school have analyzed the topic in terms of 
frequency and level of leadership practices among school leaders. The results of the analysis can be seen in Table 7 :

Table 7. Levels of Leadership Style Practice

\begin{tabular}{|c|c|c|c|}
\hline No. & Design & Findings & Author (Year) \\
\hline & $\begin{array}{l}\text { Review } \\
\text { (frequency) }\end{array}$ & $\begin{array}{l}\text { The study found that principals in } \\
\text { two SMKAs often used the } \\
\text { leadership style of the structural } \\
\text { prioritization dimension in school } \\
\text { administration. }\end{array}$ & $\begin{array}{l}\text { Jamalullail Abdul } \\
\text { Wahab, Zawiah } \\
\text { Kamad (2007) }\end{array}$ \\
\hline & $\begin{array}{l}\text { Review } \\
\text { (stage) }\end{array}$ & $\begin{array}{l}\text { SABK (SR) teachers agreed that } \\
\text { their headmaster practiced } \\
\text { instructional leadership on a } \\
\text { regular basis. }\end{array}$ & $\begin{array}{l}\text { Chitra A/P Sinnu } \\
(2019)\end{array}$ \\
\hline & $\begin{array}{l}\text { Review } \\
\text { (Frequency) }\end{array}$ & $\begin{array}{l}\text { Studies show that instructional } \\
\text { leadership styles are the most } \\
\text { frequently type of leadership } \\
\text { practiced. }\end{array}$ & $\begin{array}{l}\text { Lokman Mohd. Tahir, } \\
\text { Robiah Sidin (2008) }\end{array}$ \\
\hline & $\begin{array}{l}\text { Review } \\
\text { (Frequency) }\end{array}$ & $\begin{array}{l}\text { Studies show that instructional } \\
\text { leadership styles are the most } \\
\text { frequently type of leadership } \\
\text { practiced. }\end{array}$ & $\begin{array}{l}\text { Lokman Mohd. Tahir, } \\
\text { Robiah Sidin (2008) }\end{array}$ \\
\hline & $\begin{array}{l}\text { Review } \\
\text { (Stage) }\end{array}$ & $\begin{array}{l}\text { Teachers' perception of the level } \\
\text { of rabbinic leadership practice of } \\
\text { their principals was moderate. }\end{array}$ & $\begin{array}{l}\text { Lokman Mohd. Tahir, } \\
\text { Robiah Sidin (2008) }\end{array}$ \\
\hline & $\begin{array}{l}\text { Review } \\
\text { (Stage) }\end{array}$ & $\begin{array}{l}\text { The results showed that the } \\
\text { sustainable leadership practices of } \\
\text { the principals in the schools were } \\
\text { found to be at a moderate level. }\end{array}$ & $\begin{array}{l}\text { Shabita Md. Hussain } \\
\text { dan \& Azlin, Norhaini } \\
\text { Mansor (2016) }\end{array}$ \\
\hline & $\begin{array}{l}\text { Review } \\
\text { (Stage) }\end{array}$ & $\begin{array}{l}\text { Studies show that the level of } \\
\text { instructional leadership practice } \\
\text { of the Principals within SMKA is } \\
\text { high. }\end{array}$ & $\begin{array}{l}\text { Samsiah binti Si- } \\
\text { Rajab, Khalip Musa } \\
\text { (2019) }\end{array}$ \\
\hline & $\begin{array}{l}\text { Review } \\
\text { (Stage) }\end{array}$ & $\begin{array}{l}\text { Studies of teachers' 'perceptions } \\
\text { show that the level of autocratic } \\
\text { leadership style of their } \\
\text { headmaster is high. }\end{array}$ & $\begin{array}{l}\text { Nurlaili Abd Wahab, } \\
\text { Mohd Yusof Abdullah } \\
\text { (2018) }\end{array}$ \\
\hline & $\begin{array}{l}\text { Review } \\
\text { (Stage) }\end{array}$ & $\begin{array}{l}\text { Studies of teachers' 'perceptions } \\
\text { show that the level of democratic } \\
\text { leadership style of their } \\
\text { headmaster is high. }\end{array}$ & $\begin{array}{l}\text { Nurlaili Abd Wahab, } \\
\text { Mohd Yusof Abdullah } \\
\text { (2018) }\end{array}$ \\
\hline
\end{tabular}




\begin{tabular}{|c|c|c|}
\hline $\begin{array}{l}\text { Review } \\
\text { (Stage) }\end{array}$ & $\begin{array}{l}\text { Studies of teachers' 'perceptions } \\
\text { show that the level of liberal } \\
\text { leadership style of their } \\
\text { headmaster is high. }\end{array}$ & $\begin{array}{l}\text { Nurlaili Abd Wahab, } \\
\text { Mohd Yusof Abdullah } \\
\text { (2018) }\end{array}$ \\
\hline $\begin{array}{l}\text { Review } \\
\text { (Stage) }\end{array}$ & $\begin{array}{l}\text { Principals' perception of the level } \\
\text { of their rabbinic leadership } \\
\text { practice is high. }\end{array}$ & $\begin{array}{l}\text { Hailan Salamun \& } \\
\text { Rahimah Hj. Ahmad } \\
\text { (2012) }\end{array}$ \\
\hline $\begin{array}{l}\text { Review } \\
\text { (Stage) }\end{array}$ & $\begin{array}{l}\text { From the descriptive analysis, it } \\
\text { was found that the level of } \\
\text { effective school characteristics } \\
\text { management practices among } \\
\text { administrators in SRAI is } \\
\text { considered to be high with a mean } \\
\text { value of } 3.72 \text { and a standard } \\
\text { deviation of } 0.482 \text {. }\end{array}$ & $\begin{array}{l}\text { Jamalullail Abdul } \\
\text { Wahab, Nor'azlin } \\
\text { Salamun@Mohamed, } \\
\text { Ameer Hazim } \\
\text { Mustapa, Fairous } \\
\text { Ismail, Md. Fuad Md. } \\
\text { Rafik (2012) }\end{array}$ \\
\hline $\begin{array}{l}\text { Review } \\
\text { (Stage) }\end{array}$ & $\begin{array}{l}\text { The level of transformational } \\
\text { leadership practices of SAR } \\
\text { principals in the state of Kedah is } \\
\text { high. }\end{array}$ & $\begin{array}{l}\text { Azizi Abu Bakar, } \\
\text { Mohd Nor Jaafar, } \\
\text { Jazmi Md. Isa, } \\
\text { Shuhairimi Abdullah } \\
\text { (2014) }\end{array}$ \\
\hline
\end{tabular}

The first theme of the findings of the madrasah's leadership study that has been identified by the researchers is the level of leadership style practice among madrasah's leaders in Malaysia. Based on Table 7 , the overall level of leadership style practice applied by principals is quite high. Specifically, this study found that the practices of such leadership styles are instructional leadership, autocratic leadership, democratic leadership, independent leadership style, rabbinic leadership, effective school managerial practices, and transformational leadership.

However, there are also studies that use the word "often" to describe the frequency of leadership style practices among principals at schools/madrasahs. This study found that the most common/most frequently practiced leadership style applied were dimensional leadership, structural priorities, and instructional leadership. While the practice of rabbinic leadership and sustainable leadership is at a moderate level. 


\section{The Second Theme: The Impact of Leadership Style Practices}

Some of the previous researchs have also focused on the relationship between leadership style practices and several variables. In other words, previous researchers have already analyzed the effect of particular leadership style practice of religious-based school's leaders on dependent variables such as teacher's job satisfaction, teacher's self-efficacy, teacher's motivation, teacher's commitment and some demographic factors. Details of the findings related to this matter can be seen in the following Table 8 below:

Table 8. The Effect of Leadership Style Practices

\begin{tabular}{|c|c|c|c|}
\hline No. & $\begin{array}{l}\text { Research } \\
\text { Design }\end{array}$ & Findings & Author (Year) \\
\hline & Correlation & $\begin{array}{l}\text { From Pearson's correlation analysis, it } \\
\text { was found that there was a significant } \\
\text { relationship between principals' } \\
\text { leadership style with teachers' job } \\
\text { satisfaction. }\end{array}$ & $\begin{array}{l}\text { Shabita Md. } \\
\text { Hussain dan \& } \\
\text { Azlin, Norhaini } \\
\text { Mansor (2016) }\end{array}$ \\
\hline & Correlation & $\begin{array}{l}\text { The results of Pearson's correlation } \\
\text { analysis suggested that the autocratic } \\
\text { leadership style applied by principals } \\
\text { had a significant relationship with } \\
\text { teacher's job satisfaction. }\end{array}$ & $\begin{array}{l}\text { Shabita Md. } \\
\text { Hussain dan \& } \\
\text { Azlin, Norhaini } \\
\text { Mansor (2016) }\end{array}$ \\
\hline & Correlation & $\begin{array}{l}\text { The results of Pearson's correlation } \\
\text { analysis indicated that the democratic } \\
\text { leadership style applied by principals } \\
\text { had a significant relationship with } \\
\text { teacher's job satisfaction. }\end{array}$ & $\begin{array}{l}\text { Shabita Md. } \\
\text { Hussain dan \& } \\
\text { Azlin, Norhaini } \\
\text { Mansor (2016) }\end{array}$ \\
\hline & Correlation & $\begin{array}{l}\text { The results of Pearson's correlation } \\
\text { analysis found that the liberal } \\
\text { leadership style applied by principals } \\
\text { had a significant relationship with } \\
\text { teacher's job satisfaction. }\end{array}$ & $\begin{array}{l}\text { Shabita Md. } \\
\text { Hussain dan \& } \\
\text { Azlin, Norhaini } \\
\text { Mansor (2016) }\end{array}$ \\
\hline & Correlation & $\begin{array}{l}\text { The analysis result shows that } \\
\text { principals' transformational leadership } \\
\text { influences teachers' self -efficacy. }\end{array}$ & $\begin{array}{l}\text { Mohd Nor Jaafar, } \\
\text { Jazmi Isa (2015) }\end{array}$ \\
\hline & Correlation & The study suggested that there is a & Mohd Nor Jaafar, \\
\hline
\end{tabular}


JIEMAN: Journal of Islamic Educational Management

\begin{tabular}{|c|c|c|c|}
\hline No. & $\begin{array}{l}\text { Research } \\
\text { Design }\end{array}$ & Findings & Author (Year) \\
\hline & & $\begin{array}{l}\text { significant relationship between the } \\
\text { leadership style of principals in two } \\
\text { SMKAs with teacher's motivation. }\end{array}$ & Jazmi Isa (2015) \\
\hline & Correlation & $\begin{array}{l}\text { The study revealed that there was a } \\
\text { significant relationship between the } \\
\text { leadership style of the principals of the } \\
\text { mindfulness dimension with the level of } \\
\text { teacher motivation }\end{array}$ & $\begin{array}{l}\text { Mohd Nor Jaafar, } \\
\text { Jazmi Isa (2015) }\end{array}$ \\
\hline & Correlation & $\begin{array}{l}\text { There is a significant relationship } \\
\text { between the transformational } \\
\text { leadership style applied by principals of } \\
\text { SAR with the organizational } \\
\text { commitment of SAR teachers in Kedah. }\end{array}$ & $\begin{array}{l}\text { Mohd Nor Jaafar, } \\
\text { Jazmi Isa (2015) }\end{array}$ \\
\hline & Correlation & $\begin{array}{l}\text { The findings indicate that there is a } \\
\text { significant relationship between } \\
\text { principals 'sustainable leadership } \\
\text { practices with teachers' organizational } \\
\text { commitment. }\end{array}$ & $\begin{array}{l}\text { Mohd Nor Jaafar, } \\
\text { Jazmi Isa (2015) }\end{array}$ \\
\hline & Correlation & $\begin{array}{l}\text { The analysis showed that there was no } \\
\text { significant relationship between } \\
\text { instructional leadership applied by } \\
\text { principals for defining school objective } \\
\text { with teacher's work commitment. }\end{array}$ & $\begin{array}{l}\text { Chitra A/P Sinnu } \\
(2019)\end{array}$ \\
\hline & Correlation & $\begin{array}{l}\text { The analysis shows that there was no } \\
\text { significant relationship between } \\
\text { instructional leadership for managing } \\
\text { instructional programs with teachers } \\
\text { 'work commitment. }\end{array}$ & $\begin{array}{l}\text { Chitra A/P Sinnu } \\
(2019)\end{array}$ \\
\hline & Correlation & $\begin{array}{l}\text { The study indicates that demographic } \\
\text { factors of principals did not influence } \\
\text { their leadership style. }\end{array}$ & $\begin{array}{l}\text { Dg. Maimunah } \\
\text { Hj. Sidek, Dg. } \\
\text { Norizah Ag. } \\
\text { Kiflee (2017) }\end{array}$ \\
\hline & Correlation & $\begin{array}{l}\text { The study found that there was no } \\
\text { significant relationship between the } \\
\text { leadership's supremacy of the structural } \\
\text { prioritization dimension with the level } \\
\text { of teacher's motivation. }\end{array}$ & $\begin{array}{l}\text { Dg. Maimunah } \\
\text { Hj. Sidek, Dg. } \\
\text { Norizah Ag. } \\
\text { Kiflee (2017) }\end{array}$ \\
\hline
\end{tabular}

Referring to the findings above, this theme concerns with studies that uses correlational type of research to find the 
relationship between leadership style practices and several dependent variables. Based on Table 8 , it can said that the influence of leadership style practices on most of the dependent variables studied has significant results. From this, it suggests that the application of leadership style affect the teacher's job satisfaction level, teacher's self-efficacy, teacher's motivation and teacher's commitment. Moreover, this study also found that the demographic factors of madrasa's leaders did not affect their leadership style.

\section{The Third Theme: Different Levels of Leadership Style Practice}

Previous research has also looked at differences in leadership style practices among leaders within religious-based school according to school's type and its location. The details are as follows:

Table 9. Differences in Leadership Style Practice Levels

\begin{tabular}{|c|c|c|c|}
\hline No. & Design & Findings & Author (Year) \\
\hline & $\begin{array}{l}\text { Correlation } \\
\text { (Differences) }\end{array}$ & $\begin{array}{l}\text { The study found that the } \\
\text { transformational leadership } \\
\text { practices of principals showed } \\
\text { significant differences with } \\
\text { Maktab Mahmud as the highest } \\
\text { one followed by SABK and SAR. }\end{array}$ & $\begin{array}{l}\text { Mohd Nor Jaafar, Jazmi } \\
\text { Isa (2015) }\end{array}$ \\
\hline & $\begin{array}{l}\text { Correlation } \\
\text { (Differences) }\end{array}$ & $\begin{array}{l}\text { There are significant differences } \\
\text { between instructional } \\
\text { leadership practices in SBP, SM } \\
\text { Khas, and SM Harian with } \\
\text { SMKA, SABK and SM } \\
\text { Vocational. }\end{array}$ & $\begin{array}{l}\text { Mohd Nor Jaafar, Jazmi } \\
\text { Isa (2015) }\end{array}$ \\
\hline & Review & $\begin{array}{l}\text { The study showed that SMKA } \\
\text { principals practiced rabbinic } \\
\text { leadership at varying levels } \\
\text { according to the types of school. }\end{array}$ & $\begin{array}{l}\text { Hailan Salamun \& } \\
\text { Rahimah Hj. Ahmad } \\
(\mathbf{2 0 1 2 )}\end{array}$ \\
\hline & Review & $\begin{array}{l}\text { The findings indicate that there } \\
\text { is no significant difference in } \\
\text { the level of school's } \\
\text { characteristics within }\end{array}$ & $\begin{array}{l}\text { Jamalullail Abdul } \\
\text { Wahab, Nor'azlin } \\
\text { Salamun@Mohamed, } \\
\text { Ameer Hazim Mustapa, }\end{array}$ \\
\hline
\end{tabular}


JIEMAN: Journal of Islamic Educational Management

managerial practices among administrators based on its Fairous Ismail, Md. location.

Fuad Md. Rafik (2012)

The third theme is related to the efforts in finding differences in the level of leadership style practice by school, type of school and school location. From Table 9, it explains that the level of leadership style practice varies based on school type, but it is not by its location.

\section{The Fourth Theme: Exploring the Practice of Leadership Styles}

The results of the analysis also found that there were studies that used a qualitative approach. This study has explored the practice of leadership styles focused on instructional leadership. The details of the findings are as shown in the following Table 10:

Table 10. Exploration of Leadership Style Practices

\begin{tabular}{lll}
\hline Design & Findings & Author (Year) \\
\hline Qualitative & The findings of the study suggest that the & Jamelaa Bibi \\
(Survey) & instructional leadership practiced by & Abdullah, \\
& principals takes place in all types of & Jainabee Md \\
& schools including SMKA and SABK & Kassim (2013) \\
\hline
\end{tabular}

Table 10 shows the exploratory themes of leadership style practices that were explored by madrasah's leaders. This theme is considered to be unique because it is coming from the qualitative research employing qualitative approach as opposed to the three initial themes mentioned above which use a quantitative approach.

\section{Discussion}

One of the responsibilities of a leader is to ensure that his followers implement well-planned goals. Leaders who succeed in realizing these goals are considered to be effective leaders. To be effective leaders, ones can choose to use a variety of available leadership styles as a theory-driven choice. An effective leader is a 
leader who has a good leadership style in terms of communication skills, self-confidence, and certain behaviors as stated in several leadership theories. ${ }^{23}$ In line with this, Hallinger and Wang stated that the diversity of leadership styles implemented by school leaders can have different impacts on the school's atmosphere. ${ }^{24}$ Therefore, previous studies that sampled this meta-analysis research focused on research related to leadership style. Although this study revealed that the study of leadership within religiousbased school is relatively small compared to studies in other education fields, the researcher has managed to analyze and find some findings as described above.

First, based on the first objective, this study has found several domains and subdomains alongside with the findings of this problem. The domain that has become the research sample related to the leadership style applied in religious-based schools, followed by instructional leadership and transformational leadership. In addition, the rabbinic leadership style, effective managerial practices, and sustainable leadership were also studied by previous researchers. Among the reasons that prompted previous researchers to focus on these domains, especially leadership styles, both instructional and transformational leadership, is the focus of various parties on leadership styles and forms in the years of research carried out, including PPPM itself which emphasizes leadership, both in instructional and transformational leadership. ${ }^{25}$ As with effective managerial practices among principals of schools/madrasahs, there are two studies that examine such matter.

Likewise, rabbinic leadership is also one of the domains or leadership styles found. Research conducted in 2012, which was

${ }^{23}$ T. Correia, "Understanding Leadership Effectiveness in Organizational Settings: an Integrative Approach” [University of Lisbon]. In University of Lisbon (Issue January), (2015).

24 Philip Hallinger \& Wen-Chung Wang. Assessing instructional leadership with the Principal Instructional Management Rating Scale. Springer, 2015 .

${ }^{25}$ KPM. Pelan Pembangunan Pendidikan Malaysia 2013 - 2025. Education, Vol. 27 Issue 1 (2013). 
around the years of the implementation of the Ulul Albab Program, also became a phenomenon in Islamic Education because around 2012 the Ulul Albab Program was hotly discussed among stakeholders. ${ }^{26}$ This discussion shows that various leadership styles have been practiced among religious-based school leaders such as instructional style, transformation and others as highlighted above. Regardless of the leadership style practiced, scholars argue that leaders should not be too rigid in following a particular leadership style for two main reasons; first, over the reasons that the theory of leadership itself continues to evolve over time; and second, what is more important is that the leadership style itself should be modified based on the local environmental context. ${ }^{27}$

The second thing that becomes the core of this meta-analysis research is in terms of research methodology consisting of research design, methods, data collection methods, and research samples used. Out of all research samples, 10/12 used quantitative methods and the remaining two studies used qualitative methods and mixed approaches.

Talking about research methods or methods, it is common knowledge that research methodology is an important basis for conducting research. Some experts stated that the determination of the method, sample, and any other aspects related to the research itself must be based on the research objectives. When the purpose of the research is to explore a concept or phenomenon, the appropriate research method to be used is qualitative. However, if the research objective is to identify certain variables or factors, the appropriate method to be used is quantitative. ${ }^{28}$ Therefore, the

${ }^{26}$ Arniyuzie Mohd Arshad, B. Ulasan sistematik: Program Ulul Albab dalam sistem pendidikan di Malaysia. Jurnal Kurikulum \& Pengajajran Asia Pasifik, Vol. 3 Issue 4 (2015), 22-35.

27 Zakeer Ahmed Khan, Nawaz Allah, \& Irfanullah Khan. Leadership theories and styles: A literature review. Journal of Resources Development and Management, 16 (January, 2016).

${ }^{28}$ John W. Creswell and J. David Creswell. Research design: Qualitative, quantitative and mixed methods approaches. In Journal of Chemical Information and Modeling, Vol. 53, Issue 9 (2018). 
determination of the method used by previous researchers is in line with the views of the scholars in terms of suitability of the research design with the research objectives. This can also be used as guidance for future researchers how important it is to master various research methods and also to be more careful in determining the methods so that the research objectives are successfully achieved.

However, based on the findings, it strengthen the claim made by Gordon and Yukl's that research in leadership are too bland and overused the survey-type studies and using less diverse methods. ${ }^{29}$ This is due to the fact that almost all research samples used quantitative and survey methods, while only one research sample using qualitative study and a mixed approach, which the sample coverage only focused on certain localities or states.

Furthermore, the third essence of this study is the main findings of the study. The main findings are broken down into four parts; (a) level of leadership style practice, (b) influence of leadership style, (c) differences in leadership style practiced according to type of school and its location, and the last is (d) exploration of leadership style practice. From the aspect of leadership style, an effective leader is a leader who wisely chooses a leadership style and capable at making adjustments to his leadership style based on the needs of the organization he leads. This is because the organization is dynamic as a result of its response to the environment. ${ }^{30}$

The next essence is related to the influence of leadership style when some previous research has examined the effect of the practice of several leadership styles among religious-based school leaders on teacher's job satisfaction, teacher's self-efficacy, teacher's

${ }^{29}$ Angela Gordon and Gary Yukl. The future of leadership: Challenges and opportunities. Journal of Nursing Administration, Vol. 18 Issue 3 (2004), 359368.

$3^{30}$ Alex A. Jaleha and Vincent N. Machuki. Strategic leadership and organizational performance: A critical review of literature. European Scientific Journal ESJ, Vol. 14 Issue 35 (2018), 124-149. 
JIEMAN: Journal of Islamic Educational Management

motivation, and teacher's commitment. Moreover, some of the previous studies also examined the influence of demographic factors on leadership styles at school. It is undeniable that leadership is one of the main instruments of improving school performance. This is explained by a study that examines three leadership styles, namely autocratic leadership, democratic leadership, and liberal leadership style (laissez faire style). The research findings suggest that leadership style has a very strong relationship with the success of an organization. The approach used by leaders to gain respect from their employees can be indicator to determine organizational performance. ${ }^{31}$ Further, the result of the study also showed that democratic leadership style is the most effective one compared to autocratic and liberal leadership style.

However, it is very unnecessary to say that such a democratic leadership style is the most effective one to be applied as some results of other study claim otherwise. This is because leadership is not one size fits all, but it needs some consideration to choose which leadership style to be adapted to meet and accomplish the needs of the organization, environment, members, location and so on. ${ }^{32}$ For instance, according to one of the research samples, it was found that the instructional leadership practices between SBP, SM Khas, and SM Harian with SMKA, SABK and Technical/Vocational SM differ because the focus set by principals is different. ${ }^{33}$ This is because the Principals of SMKA, SABK, and Technical/Vocational Schools are more focused on increasing the knowledge and teaching skills of teachers by considering the needs of students in

${ }^{31}$ Jee Fenn Chung and Akram Abdulraqeb Sultan Al-Khaled. The impact of leadership styles on organizational performance. BERJAYA Journal of Services \& Management, 13 (2020), 55-62.

32 Rose Ngozi Amanchukwu, Gloria Jones Stanley, and Nwachukwu Prince Ololube. A review of leadership theories, principles and styles and their relevance to educational management. Management, Vol. 5 Issue 1 (2015), 6-14.

${ }^{33}$ Mohd Nor Jaafar \& Jazmi Md Isa. Pengaruh kepemimpinan transformasi pengetua terhadap efikasi guru di tiga jenis sekolah menengah agama. International Conference on Educational, 1, (2015), 875-885. 
schools that require teachers who really master technical as well as religious-based skills.

\section{Conclusion}

This meta-analysis study focuses on the domain of leadership research which includes the approach or leadership style, the types of research methods used, and the findings of previous research. Various leadership styles have been practiced among school leaders. However, at the same time continuous improvement needs to be made in line with lifelong learning and the concept of Professional Learning Community (PLC). Diverse research methods are essential to produce broader findings and the needs to cover various aspects of leadership having larger sample sizes and involve more comprehensive study sites. Determination of the method must be done based on the needs and objectives to be achieved. Studies have found that leadership styles are flexible and need to constantly adapt to changing times and places. The leadership style of a religious-based school leader can affect many aspects which in turn can affect school's achievement and performance.

\section{References}

Abd Rahim, Saiful Adli, et al. "Teacher Leadership Models: A Directed Analysis of Content." 40o(Icream 2019), 172-176.

Abd Wahab, Nurlaili, and Mohd Yusof Abdullah. "Hubungan Gaya Kepimpinan dan Pengurusan Kerja Guru Besar dengan Kepuasan Kerja Guru Sekolah Agama Kerajaan Johor.” Jurnal Ilmi, 8 (2018), 136-150.

Abdullah, Jamelaa Bibi, and Janaibee Md Kassim. “Amalan Kepimpinan Instruksional dalam Kalangan Pengetua Sekolah Menengah di Negeri Pahang: Satu Kajian Kualitatif." Seminar Nasional Pengurusan Dan Kepimpinan Pendidikan, 23 (2013). 
Amanchukwu, Rose Ngozi, Gloria Jones Stanley, and Nwachukwu Prince Ololube. "A Review of Leadership Theories, Principles and Styles and Their Relevance to Educational Management." Management, Vol. 5 Issue 1 (2015), 6-14.

Amin, Mohd Hairudin, and Kamarul Azmi Jasmi. "Sekolah Agama di Malaysia: Sejarah, Isu dan Cabaran.” Univerti Teknologi Malaysia, 2012.

Arniyuzie Mohd Arshad, B. "Ulasan Sistematik: Program Ulul Albab dalam Sistem Pendidikan di Malaysia." Jurnal Kurikulum $\mathcal{E}$ Pengajajran Asia Pasifik, Vol. 3 Issue 4 (2015), 22-35.

Asmawati Suhid, B., Abd Muhsin Ahmad, B., Syaza Mohd Sabri, B., \& Azreen Effendy Mohamad, B. "Pendidikan untuk Semua: Amalannya dalam Sistem Pendidikan Islam di Malaysia." International Journal of Education and Training (InjET), Vol. 1 Issue 5 (2015), 1-7.

Asrar-ul-Haq, Muhammad, and Sadia Anwar. "The Many Faces of Leadership: Proposing Research Agenda through a Review of Literature." Future Business Journal, Vol. 4 Issue 2 (2018), 179-188.

Awfik, Gehad Mohamed, et al. "A Step by Step Guide for Conducting a Systematic Review and Meta-Analysis with Simulation Data." Tropical Medicine and Health, Vol. 47 Issue 1 (2019).

Azizi, Abu Bakar, Mohd Nor, J., Jazmi, M. I., \& Shuhairimi, A. "Transformation Leadership at the Sekolah Agama Rakyat: A Purpose Towards the Development of Education." Journal of Human Development and Communication, 3 (2014), 1-7.

Beekun, Rafik Issa, and Jamal A. Badawi. Leadership : An Islamic Perspective. St. Mary’s University, 1998. 
Bolden, Richard. "Distributed Leadership in Organisations: A Review of Theory and Research." International Journal of Management Reviews, 13, (2011), 251-269.

Chin, Jean Lau. "Introduction to the Special Issue on Diversity and Leadership." American Psychologist, Vol. 65 Issue 3 (2010), 150-156.

Chitra A/P Sinnu. "Hubungan Kepimpinan Instruksional Guru Besar dengan Komitmen Kerja Guru Sekolah Agama di Negeri Melaka." Journal of Ilmi, 9 (2019), 1-14.

Chung, Jee Fenn, and Akram Abdulraqeb Sultan Al-Khaled. "The Impact of Leadership Styles on Organizational Performance." BERJAYA Journal of Services \& Management, 13 (2020), 55-62.

Clarke, Simon, and Tom O’Donoghue. "Educational Leadership and Context: A Rendering of an Inseparable Relationship." British Journal of Educational Studies, (2016), 167-182.

Collard, John. "Effective Educational Leadership." Journal of Educational Administration, Vol. 43 Issue 5 (2005), 520-521.

Correia, T. "Understanding Leadership Effectiveness in Organizational Settings: an Integrative Approach." [University of Lisbon]. In University of Lisbon (Issue January), (2015).

Creswell, John W., and J. David Creswell. "Research Design: Qualitative, Quantitative and Mixed Methods Approaches." Journal of Chemical Information and Modeling, Vol. 53, Issue 9 (2018).

Dg Maimunah, S., \& Dg Norizah, A. K. "Gaya Kepimpinan Guru Besar terhadap Motivasi Kerja Guru Sekolah Agama Negeri Pedalaman Bawah.” Seminar Kebangsaan Majilis Dekan Pendidikan Universiti Awam 2017, (2017), 78-89. 
Dumdum, Uldarico Rex, Kevin B. Lowe, and Bruce J. Avolio. "A Meta-Analysis of Transformational and Transactional Leadership Correlates of Effectiveness and Satisfaction: An Update and Extension." In Transformational and Charismatic Leadership: The Road Ahead 1oth Anniversary Edition. Emerald Insight, Vol. 2 (2015) pp. 35-66.

Fauzi Sulehan. Amalan Kepimpinan Lestari Pengetua Sekolah Agama Bantuan Kerajaan (SABK) di Daerah Pontian. Universiti Teknologi Malaysia, 2013

Fiedler, Fred E. "A Contingency Model of Leadership Effectiveness." Advances in Experimental Social Psychology, 1(C) (1964), 149-190.

Galanou, Aikaterini, and Dalia Abdelrahman Farrag. "Towards the Distinctive Islamic Mode of Leadership in Business." Journal of Management Development, (2015).

Gordon, Angela, and Gary Yukl. "The Future of Leadership: Challenges and Opportunities." Journal of Nursing Administration, Vol. 18 Issue 3 (2004), 359-368.

Hailan Salamun, B., \& Rahimah Hj. Ahmad. "Daya Kepimpinan Rabbani Pengetua Sekolah Menengah Kebangsaan Agama (SMKA)." In Institut Aminudin Baki (Ed.), Seminar Nasional Pengurusan dan Kepimpinan Pendidikan ke-17, (2010) (p. 56).

Hailan Salamun, B., \& Rahimah Hj. Ahmad. "Daya Kepemimpinan Rabbani Pengetua Sekolah Menengah Kebangsaan Agama (SMKA)." Jurnal Internasional Manajemen Pendidikan, 4(02), 35-51.

Hallinger, Philip, \& Wen-Chung Wang. “Assessing Instructional Leadership with the Principal Instructional Management Rating Scale." Springer, 2015. 
Hitti, Philip K., Ibn-Khaldun, \& Franz Rosenthal. "The Muqaddimah: An Introduction to History." The American Historical Review, Vol. 64 Issue 3 (1959), 659.

Jaleha, Alex A., and Vincent N. Machuki. "Strategic Leadership and Organizational Performance: A Critical Review of Literature." European Scientific Journal ESJ, Vol. 14 Issue 35 (2018), 124-149.

Jamalullail, Abdul Wahab, et. al. "Amalan Pengurusan Sekolah Berkesan Pentadbir Sekolah Rendah Agama Intergrasi Negeri Selangor." Jurnal Pengurusan dan Kepimpinan Pendidikan, Vol. 24 Issue 2 (2012), 31-43.

Jamalullail, Abdul Wahab, et. al. "Hubungan Antara Gaya Kepimpinan Pengetua dengan Motivasi Guru Sekolah Menengah Agama." Jurnal Pengurusan dan Kepimpinan Pendidikan, Vol. 17 Issue 2 (2007).

Khan, Zakeer Ahmed, Nawaz Allah, \& Irfanullah Khan. "Leadership Theories and Styles: A Literature Review." Journal of Resources Development and Management, 16 (January, 2016).

KIPP. Leadership Framework and Competency Model. The Knowledge Is Power Program (KIPP), 2018.

Klaus, S. The Fourth Industrial Revolution. In World Economic Forum Crown Business, 2018, (pp. 49-78).

KPM. Buku Perangkaan Pendidikan Malaysia 2020. Kementerian Pendidikan Malaysia, 2020.

KPM. Dasar Pendidikan Kebangsaan. Kementerian Pendidikan Malaysia, 2017a.

KPM. Laporan tahunan Pelan Pembangunan Pendidikan Malaysia Tahun 2013. In Kementerian Pendidikan Malaysia, Vol. 27, Issue 1 (2014). 
JIEMAN: Journal of Islamic Educational Management

KPM. Pelan Pembangunan Pendidikan Malaysia 2013-2025. Education, Vol. 27 Issue 1 (2013).

KPM. Standard Kualiti Pendidikan Malaysia Gelombang 2 (2017b) 18.

Kurilovas, Eugenijus. “On Data-Driven Decision-Making for Quality Education." Computers in Human Behavior, 107 (June) 2018, $1-9$.

Leithwood, K., \& Levin, B. "Understanding How Leadership Influences Student Learning." International Encyclopedia of Education, (2010), 45-50.

Mohd Nor Jaafar, \& Jazmi Md Isa. "Pengaruh Kepemimpinan Transformasi Pengetua Terhadap Efikasi Guru di Tiga Jenis Sekolah Menengah Agama." International Conference on Educational, 1, (2015), 875-885.

Mohd Roslan Mohd Nor, B., \& Wan Mohd Tarmizi Wan Othman, B. "Sejarah dan Perkembangan Pendidikan Islam di Malaysia." Jurnal Al-Ta'dib, Vol. 6 Issue 1 (2011), 1-20.

Moher, David, et al. "Preferred Reporting Items for Systematic Review and Meta-Analysis Protocols (Prisma-P) 2015 Statement." Systematic Reviews Journal, Vol. 4 Issue 1 (2015), 3-9.

Moldoveanu, Mihnea, and Das Narayandas. "The Future of Leadership Development." Harvard Business Review, (March-April 2019).

Moten, Abdul Rashid. "Leadership in the West and the Islamic World: A Comparative Analysis." World Applied Sciences Journal, Vol. 15 Issue 3 (2011), 339-349.

Muhamed Solih. "Exploring the Influence of Islamic Spritual Intelligence, Emotional Intelligence on Students Leadership 
Competencies; Islamization of Knowledge, Mediating Factor." Thesis, Vol. 21 Issue (2020), 1-9.

Muhammad Faizal A. Ghani. "Amalan Kecemerlangan Sekolah dalam Kalangan Dua Jenis Sekolah Berprestasi Tinggi di Malaysia." Atikan, Vol. 2 Issue 2 (2012), 207-234.

Noman, Mohammad, and David Gurr. "Contextual Leadership and Culture in Education." Oxford Research Encyclopedia of Education, (2020) 1-25.

Ogunbado, Ahamad Faosiy, et al. "Islamic Perspective of the Followers: A Neglected Aspect in Locus of Leadership." International Review of Management and Marketing, Volume 6 Issue 8 (Special Issue) (2016), 113-118.

Ogunbado, Ahamad Faosiy, Yusuf Sani Abubakar, \& Mpawenimana Abdallah Saidi. "Umar Ibn Khattab, an Epitome of Servant Leadership: A Sustainable Lesson for Contemporary Leaders." Journal of Critical Reviews, Vol. 7 Issue 8 (2020), 1021-1026.

Ogunbado, Ahamad Faosiy. "The Concept of Leadership in Islam : A Special Reference to Ibn Khaldun's Muqaddimah,” 2012.

Polat, Soner, Yaser Arslan, and Olcum Dincer. "Diversity Leadership Skills of School Administrators: A Scale Development Study." Issues in Educational Research, Vol. 27 Issue 3 (2017), 512-526.

Prewitt, James, Richard Weil, and Anthony McClure. "Developing Leadership in Global and Multi-Cultural Organizations. Developing the Global Organization,” Vol. 2 Issue 13 (2020), 312-324.

PRISMA. PRISMA 2020. In PRISMA, Vol. 49, Issue 1 (2020), pp. 4044 . 
Raihan, Mohd Arifin, Mat Teh Kamarul Shukri, and Abdul Wahab Noradilah. "Iklim dan Budaya : Kesan terhadap Kemenjadian Pelajar." International Conference on Islam and Global Issues, March, (2018), 736-743.

Rumman, Ayman Ahmad Abu, and Ahmad Fathi Alheet. "The Role of Researcher Competencies in Delivering Successful Research.” Information and Knowledge Management, Vol. 9 Issue. 1 (2019), 29-32.

Samsiah Si-Rajab, \& Khalip Musa. “Tahap Amalan Kepimpinan Instruksional Pengetua Sekolah Menengah Kebangsaan Agama di Malaysia." Jurnal Pengurusan dan Kepimpinan Pendidikan, Vol. 32 Issue (2019), 1-14.

Shabita, H., \& Mansor Azlin Norhaini. “Amalan Kepimpinan Lestari dan Hubungannya dengan Komitmen Guru Kolej Islam Sultan Ahmad Shah, Klang." Jurnal Kepimpinan Pendidikan, 1990, (2016), 1119-1131.

Sidani, Yusuf M. "Ibn Khaldun of North Africa: An AD 1377 theory of Leadership." Journal of Management History, Vol. 14 Vol. 1 (2008), 73-86.

Tahir, Lokman Mohd, and Robiah Sidin. "Orientasi Kepemimpinan Pengetua Sekolah Menengah di Johor: Satu Analisis.” Jurnal Teknologi, 48 (e) (2008), 85-97.

Ujil, Andrew Thomas, and Christina Andin. "Kepimpinan Sekolah Berprestasi Tinggi: Kriteria dan Pembentukan Kepimpinan.” Malaysian Journal of Social Sciences and Humanities, Vol. 3 Issue 2 (2018), 113.

Walker, Esteban, Adrian V. Hernandez, and Michael W. Kattan. "Meta-Analysis: Its Strengths and Limitations." Cleveland Clinic Journal of Medicine, Vol. 75 Issue 6 (2008), 431-439. 
Zunaidi Harun, et al.

Webster, Jane, and Richard T. Watson. "Analyzing the Past to Prepare for the Future: Writing a Literature Review." MIS Quarterly, Vol. 26 Issue 2 (2002), xiii-xxiii. 